\title{
蛙峻核的视野区域对应投射
}

蛙的峡核是位于中脑脚和小脑之间边艒上的中 脑结构. 近年来,一些解剖学、生理学和组织化学研 究表明,侠核是蛙视觉系统的一部分.

我们用电生理方法研究了黑斑蛙（Rana nigro maculata) 单个峡核单位的视觉反应和视野在 峡核 上的区域对应投射.

玻璃微电极灌注液含有 $2.5 \mathrm{MNaCl}$ 和 $50 \mathrm{mM}$ $\mathrm{CoCl}_{2}$, 根据立体坐标把电极插入峡核区域。用的视 觉刺激是黑或白圆和光点。从左峡核记录了 101 个 单位的视觉反应,并用钴染色法标记了它们的位置。 主要结果简报如下:

(1) 在峡核区域记录到的 101 个视觉单位的钴 标记位置全部在峡核内, 表明畔核本身是蛙视觉系 统的一个有限部分. 这个发现显然与 Виноградова 和 Мантейфель 用电刺激蛙视神经所得结果相抵触; 他们标记了 7 个记录位置, 但其中 3 个明显在峡核 之外,故认为峡核及其周围区域是一个视觉结构, 叫 做畉核区. 这可能表明他们用的电刺激对描绘脑中 视野代表图是不适宜的，因为它可能引起非特异性 兴奋.
（2）大部分视野，包括整个对侧半视野和同侧 半视野中央 $40^{\circ}$, 呈区域对应地投射在映核上。一般 说, 位于核内侧和腹侧的无细胞带是对侧与同侧半 视野的分界线，其背侧是对侧半视野的代表区. 把 陕核分成嘴半部和尾半部的中平面代表视野的水平 子午线. 上视野投射到嘴半部; 尾半部的中央部和 内腹侧部; 下视野的代表区在核尾半部的背部和外 侧部. 显然,二维视野在三维峡核 $(320 \times 570 \times 650$ 立方微米)上形成一个区域对应图.

（3）从左峡核上记录到 15 个双眼单位. 蛙头 前方的双眼空间包括对侧半视野中央 $40^{\circ}$ 和同侧半 视野中央 $30^{\circ}$; 在头上方, 双眼区至少占据对侧半视 野 $10^{\circ}$ 和同侧半视野 $20^{\circ}$. 大多数双眼单位主要被 对侧眼兴奋, 其中两个几乎同等地被两个单眼兴奋。 这些双眼单位分布在浃核嘴半部的髓质内, 其感受 域大小平均比单眼单位的大一倍.

此外, 还记录到 5 个对白刺激感的单位, 和 1 个只对背景光关闭发生强烈反应的变暗单位.

\section{王书荣颜 坤王随亭}

（中国科学院生物物理研究所）

\section{根瘦菌突变株-大豆作物突变株 “双突变”共生固氮体系的研究}

我们用亚硝基胍 (N-methyl- $\mathrm{N}^{\prime}-\mathrm{nitro}-\mathrm{N}-\mathrm{nitroso-}$ guanidine) 等方法诱变得到大豆根痹菌突变株（Rh. japonicum mutant $B_{16-11}$ ) 与大豆作物突变株 (Soybean plant mutant $18-79 、 33-79 、 55-79 、 66-80 、 77-80$ 等), 在田间经同步化后，应用单粒育种法,选育出了具有 高光合强度；高固氮作用联合效应的 “双突变” 共生 固氮体系的大豆新品种 (Dss18、Dss33、Dss55 等)。

应用于共生固氮体系的大豆根瘤菌突变株 $\left(B_{16-11}\right)$ 具有自生固氮能力, 在实验室条件下能使 乙炔还原为乙烯, 固氮活性较野生型菌株 ( $\left.\mathrm{B}_{16}\right)$ 高 三倍以上.

选用作为共生固氮体系的大豆作物突变株具有 较高的光合作用强度, 其强度较未经诱变处理的大 豆高 $10 \%$ 以上.

而这种“双突变” 共生固氮体系的大豆新品种,
则具有豆叶迟衰、绿叶黄英、根瘤迟破、类菌体多、高 光合强度和高固氮活性的特征。这种共生体的生理 生化特性, 光合一固氮联合效应能力很强、很持久, 由 于这种联合效应的结果, 使大豆总干物质的积累增 加，特别是大豆的籽粒重显著地提高，田间试验结 果, “双突变”大豆共生体要比对照增 产 37-119\%。 从而可以看出,选育这种高光合一固氮联合效应的根 瘤菌突变株及大豆作物突变株基因型的“双突变”共 生固氮体系新品种，对提高豆科作物及农作物产量 有很大潜力. 进一步探讨和研究, 将具有较大的理 论和现实意义。

张宪武王书锦吴尧夫 高德恩 唐桂橎 薛德林 （中国科学院林业土壤研究所） 